\title{
The Relation of Fish Community Composition to Riparian Cover and Runoff Potential in the Minnesota River Basin, Minnesota and lowa, 1997.
}

The relation of fish community composition to riparian cover and runoff potential was investigated in 20 streams in the Minnesota River Basin during the summer of 1997 as part of the U.S. Geological Survey's National Water-Quality Assessment (NAWQA) Program (fig.1). Analysis of variance statistics indicated significant differences in the composition of the fish community due to both riparian cover (wooded or open) and runoff potential (high or low). An Index of Biotic Integrity (IBI), species richness, and diversity were used to measure the community response and health. Fish communities in streams with significant wooded riparian cover had higher IBI scores, species richness, and diversity than streams with little wooded riparian cover. Streams with low runoff potential had higher IBI scores and species richness than streams with high runoff potential. IBI scores and species richness responded independently to riparian cover and runoff potential. Although both factors were important, riparian cover influenced fish community composition more than runoff potential in these streams, indicating that local factors (close to the stream) dominate landscape or basin-wide factors (Stauffer and others, 2000).

\section{Introduction}

The physical and chemical environment within streams directly affects aquatic community composition and abundance (Karr and Schlosser, 1978). The instream physical and chemical environment is influenced by numerous factors that function at different spatial and temporal scales (Richards and others, 1996).

Features of instream habitat (local variables) such as stream hydrology, sedimentation, nutrient inputs, channel morphology (Hughes and others, 1994), and riparian vegetation (Richards and others, 1996), have long been considered when defining local aquatic community composition (Southwood, 1977).

Recently, studies that have evaluated basin-wide variables such as geology, land use, and climate, along with local variables have provided a better understanding of important linkages and controlling mechanisms in aquatic community composition (Allan and Johnson, 1997). Basin-wide factors such as climate affect local factors such as sedimentation which in turn directly affect the aquatic community composition.

Riparian cover is important to water quality conditions in agricultural basins because the riparian vegetation can directly influence aquatic communities by mediating the effects of agricultural activities (Osborne and Kovacic, 1993; Johnson and others, 1997). Riparian grasses and trees filter runoff and retain nutrients and sediment (Gregory and

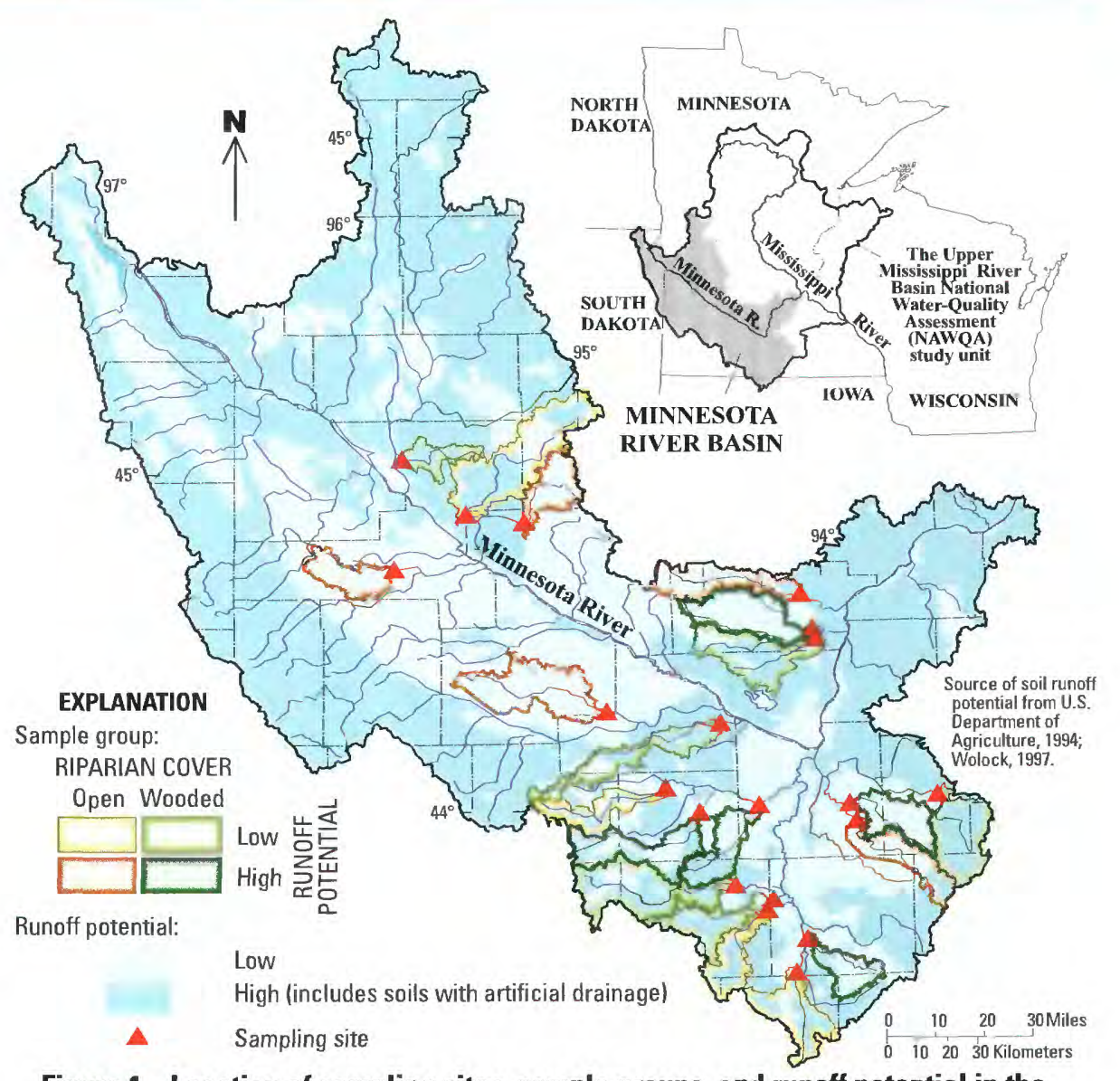

Figure 1.--Location of sampling sites, sample groups, and runoff potential in the Minnesota River Basin in the Upper Mississippi River Basin study unit.

others, 1991; Osborne and Kovacic, 1993) and directly affect aquatic communities by influencing habitat, instream temperature, and primary production, particularly in mid- to small size streams (Gregory and others, 1991).
Trees that fall into the stream provide critical fish and invertebrate habitat, retain organic matter, and influence channel morphology (Gregory and others, 1991). Inputs from riparian vegetation such as fallen leaves and 
branches provide an energy source for stream invertebrates. Stream reaches with dense vegetation canopies tend to have lower water temperatures due to shading than stream reaches without canopies (Gregory and others, 1991).

Soil characteristics are basin features that influence sediment and nutrient inputs to agricultural streams and affect the stream geomorphology. Soils composed primarily of silt and clay material limit infiltration and accelerate runoff into streams. In poorly drained soils, artificial drainage systems have been installed to improve agricultural productivity. The rate and amount of sediment, nutrients, and contaminants delivered to streams can increase in basins with artificial drainage systems (Lenat, 1984). Artificial drainage systems deliver sediment, nutrients, and contaminants directly to the stream, circumventing any protection provided by the riparian cover (Osborne and Kovacic, 1993). Thus, chemical conditions and sedimentation in these streams may be more dependent upon soil characteristics and land-use activities in the basin than on riparian cover. Soil characteristics that affect runoff potential also influence the geomorphology of streams, which can directly alter fish community composition. As the surface runoff rate increases the geomorphologic characteristics of the stream may change because of erosion and depositional processes.

The purpose of this study was to compare the influence of two factors operating at different scales, one local and the other basin wide, on the fish community composition in an agricultural setting. The local scale factor was riparian cover (wooded or open), and the basinwide scale factor was runoff potential (high or low). This study is related to a larger, regional investigation of the quality of midwestern streams and rivers (Sorenson and others, 1999). The objectives of this study were to: (1) determine if fish communities respond to differences in riparian cover and runoff potential through changes in community composition, and (2) determine which factor, riparian cover or runoff potential, has more influence on fish community composition. This fact sheet addresses the question of whether wooded riparian cover can mediate broad-scale problems created in certain agricultural basins.

\section{Methods}

Twenty perennial streams with greater than 50 percent tilled acreage, draining between $95 \mathrm{mi}^{2}$ and $314 \mathrm{mi}^{2}$ were selected to complete a two group, two level analysis matrix. The first classification factor for site selection was based on local (segment-scale) riparian cover. The length (miles) of stream segments was defined as the $\log _{10}$ of the basin area (square miles). Sites were classified as wooded or open based on the percentage of wooded riparian cover present in a 328 foot buffer along the stream for each segment. The percentage of wooded riparian area was calculated from digital raster graphics (DRG) and updated using aerial photographs from the National Aerial Photography Program (NAPP) (fig. 2).

The second classification factor for a site was based on basin-wide soil characteristics. Analysis of the State Soil Geographic data base (STATSGO) (U.S. Department of Agriculture, 1994;

Wolock, 1997), was used to determine runoff potential. The STATSGO variable "hydrologic soil group", a computed variable that categorizes soils into classes based on the inherent capacity of bare soil to permit infiltration, was used to classify sites as either high runoff potential or low runoff potential (fig. 1), based on the

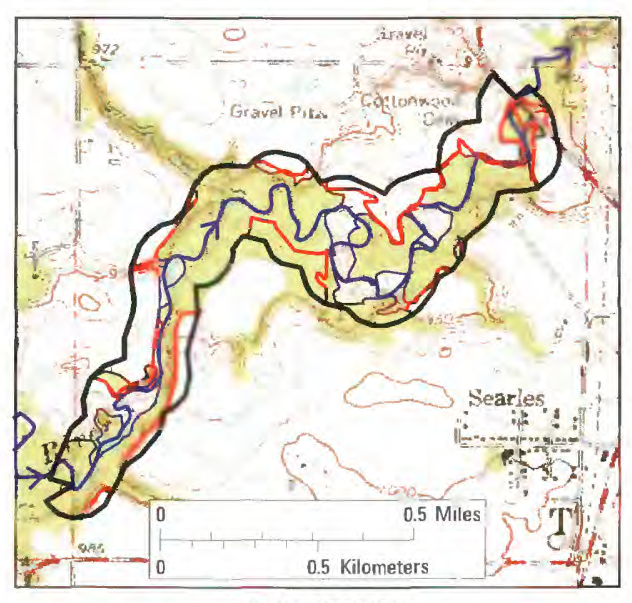

EXPLANATION

Riparian cover derived from Digital Raster Graphics (DRG)

Boundary of 328 foot buffer from center of river

Boundary of updated riparian cover (based on aerial photographs)

Mainstem of the Little Cottonwood River

Figure 2.--Riparian cover as calculated at the segment scale along the Little Cottonwood River (U.S. Geological Survey, 1980; U.S. Geological Survey, 1996). percentage of hydrologic soil group composition in the basin.

Within each segment, a reach was located and used for fish community sampling. The reach sampled was representative of the condition found in the segment. If a segment was classified as wooded based on the percent wooded area, then the reach sampled had wooded riparian cover. Stream reach length was set at least 22 times the estimated (wetted) channel width (Meador and others, 1993). The average channel width was 36 feet. The average reach length was 837 feet. When possible, each stream reach included at least two examples of two different geomorphic channel units: pool, riffle, or run.

Physical habitat in streams strongly influences fish community composition (Richards and others, 1996). Analysis of the physical habitat was conducted to identify those physical features that were associated with riparian cover and those that were associated with runoff potential. Identifying specific physical habitat variables correlated with the classification factors may reveal how wooded riparian cover and runoff potential influence fish community composition. At sites with different classification factors, physical habitat variables found to be different could be used to explain which classification factors could be affecting fish community composition.

\section{Fish Sampling}

Fish communities were sampled by electrofishing (pulsed DC). Two passes were made through each reach to collect a representative sample of the fish community. All fish were identified to species, counted and a batch species weight was determined (Meador and others, 1993). Sampling was conducted during periods of low or stable flow conditions during July to September 1997.

\section{Habitat Assessment}

At each reach, 12 transects at intervals of two average channel widths were established for measurements of instream physical habitat. A description of the physical habitat variables (Meador and others, 1993) that were measured is outlined in Stauffer (1998). Stream discharge was also measured at each site at the time of fish community sampling.

Segment-level variables, including gradient and sinuosity, were determined 
for each site using a geographic information system (GIS).

\section{Analysis}

An Index of Biotic Integrity (IBI) (Karr, 1981; Bailey and others, 1993), species richness, and Shannon diversity (Peilou, 1975) were used as fish community descriptors to measure of the fish community response and community health. The IBI contained 12 metrics related to the composition and structure of the fish community. Each metric was scored in relation to reference (least or unaffected) communities. The sum of the metric scores is the IBI score. In the IBI, six metrics evaluated species richness and composition, three metrics related to trophic composition, and three measured the abundance and condition of fish. IBI scores, which ranged from 12 to 60 , were generated from the fish community data. Two of the original metrics outlined by Karr (1981), the proportion of green sunfish and proportion of hybrids, were replaced with proportion of tolerant individuals and proportion of simple lithophils (Bailey and others, 1993).

An Analysis of Variance (ANOVA) can be used to determine the relative importance (amount of variation explained) of each of the factors and their interaction. This procedure was used to determine which factors, local or basin, were more significant in explaining variation in the fish community descriptors.

Differences in the physical habitat variables between sites were identified with a Wilcoxon signed-rank test.

Habitat variables measured for each site were categorized into seven groups: instream cover, substrate, bank condition, riparian zone variables, hydrology, habitat volume, and geomorphology (Stauffer, 1998).

\section{Results}

Significant differences in IBI scores and species richness indicate that the two classification factors, riparian cover and runoff potential, appear to influence fish community composition. About one third of the variance in IBI scores could be explained by the riparian cover classification factor. Runoff potential also explained about one third of the variance in IBI scores. The riparian cover explained more of the variance in species richness than runoff potential. The riparian cover was the only factor that explained a significant percentage of variance in diversity.

Sites with the combination of wooded riparian cover and low runoff potential were highest in mean IBI score (37.6), and sites with an open riparian cover and high runoff potential were lowest in mean IBI score $(21.2)$. There was little difference in IBI scores and species diversity between high and low

\begin{tabular}{|c|c|c|c|c|c|c|c|c|c|}
\hline & Site name & $\begin{array}{c}\text { USGS site } \\
\text { identi- } \\
\text { fication } \\
\text { number }\end{array}$ & 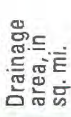 & 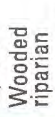 & 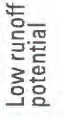 & 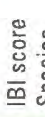 & & 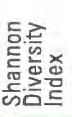 & $\begin{array}{l}\text { Group } \\
\text { IBI scores }\end{array}$ \\
\hline \multirow{5}{*}{ 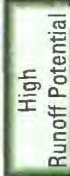 } & Coon Creek near Blue Earth, Minn & 05317828 & 95 & $44 \%$ & $18 \%$ & 38 & 16 & 1.22 & \multirow{5}{*}{$\begin{aligned} 34.0= & \text { Mean IBI } \\
& \text { score } \\
4.2= & \text { Standard } \\
& \text { deviation } \\
& \text { of IBI } \\
& \text { scores }\end{aligned}$} \\
\hline & Little Cobb River near Beauford, Minn. & 05320270 & 3.4 & $31 \%$ & $52 \%$ & 28 & 23 & 0.94 & \\
\hline & Rush River near New Rome, Minn. & 05326150 & 190 & $59 \%$ & $1 \%$ & 32 & 24 & 0.99 & \\
\hline & Perch Creek below Vernon Center, Minn. & 05319360 & 132 & $39 \%$ & $50 \%$ & 38 & 24 & 1.11 & \\
\hline & South Fork Watonwan River near St James. Minn. & 05319050 & 191 & $28 \%$ & $31 \%$ & 34 & 22 & 0.77 & \\
\hline \multirow{5}{*}{ 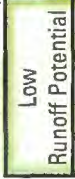 } & Dry Weather Creek near Watson, Minn. & 05304795 & 100 & $30 \%$ & $97 \%$ & 42 & 19 & 0.82 & \multirow{5}{*}{$\begin{aligned} 37.6= & \text { Mean IBI } \\
& \text { score } \\
3.6= & \text { Standard } \\
& \text { deviation } \\
& \text { of IBI } \\
& \text { scores }\end{aligned}$} \\
\hline & Elm Creek near Northrup, Minn. & 05318240 & 232 & $37 \%$ & $60 \%$ & 38 & 20 & 0.83 & \\
\hline & Le Sueur River near Wilton, Minn. & 05320080 & 172 & $40 \%$ & $95 \%$ & 40 & 23 & 0.94 & \\
\hline & Little Cottonwood River near Sarles, Minn. & 05317170 & 232 & $50 \%$ & $53 \%$ & 34 & 25 & 1.17 & \\
\hline & South Branch Rush River near Rush River, Minn. & 05326250 & 180 & $54 \%$ & $61 \%$ & 34 & 19 & 1.07 & \\
\hline \multirow{5}{*}{ 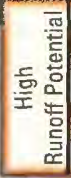 } & Cobb River near Mapleton, Minn. & 05320230 & 111 & $27 \%$ & $29 \%$ & 24 & 18 & 0.47 & \multirow{5}{*}{$\begin{aligned} 21.2= & \text { Mean IBI } \\
& \text { score } \\
3.9= & \text { Standard } \\
& \text { deviation } \\
& \text { of } \mid \mathrm{BI} \\
& \text { scores }\end{aligned}$} \\
\hline & Chetomba Creek near Renville, Minn. & 05314510 & 120 & $0 \%$ & $0 \%$ & 20 & 7 & 0.73 & \\
\hline & High Island Creek near Arlington, Minn. & 05326700 & 163 & $2 \%$ & $9 \%$ & 16 & 12 & 0.72 & \\
\hline & Sleepy Eye Creek near Springfield, Minn. & 05316985 & 255 & $0 \%$ & $2 \%$ & 26 & 17 & 0.85 & \\
\hline & Spring Creek near Spring Creek, Minn. & 05312000 & 112 & $9 \%$ & $0 \%$ & 20 & 13 & 0.72 & \\
\hline \multirow{5}{*}{ 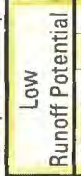 } & Center Creek at Huntley, Minn. & 05318178 & 111 & $\underline{0} \%$ & $81 \%$ & 38 & 20 & 0.68 & \multirow{5}{*}{$\begin{aligned} 33.2= & \text { IMean IBI } \\
& \text { score } \\
5.0= & \text { Standard } \\
& \text { deviation } \\
& \text { of IBI } \\
& \text { scores }\end{aligned}$} \\
\hline & Hawk River near Maynard, Minn. & 05314500 & 314 & $3 \%$ & $66 \%$ & 34 & 24 & 1.07 & \\
\hline & South Creek near Huntley, Minn. & 05318138 & 104 & $3 \%$ & $91 \%$ & 28 & 19 & 0.84 & \\
\hline & Watonwan River near St James, Minn. & 05318630 & 100 & $10 \%$ & $51 \%$ & 28 & 20 & 0.52 & \\
\hline & West Branch Blue Earth River above Elmore, Minn. & 05317800 & 148 & $6 \%$ & $78 \%$ & 38 & 17 & 0.86 & \\
\hline
\end{tabular}

runoff potential sites with wooded riparian cover, however, there was a significant decrease in both IBI scores and species richness between high and low runoff potential sites with open riparian cover (table 1). Although the interaction of the two classification factors was not significant at the 0.05 level, there was a marginal interaction for IBI scores and species richness $(\mathrm{P}=0.06)$. This marginal interaction suggests that IBI scores and species richness at sites in high runoff potential basins are more influenced by the presence or absence of a wooded riparian cover.

Most of the differences between the physical habitat were between wooded and open riparian cover sites, not between high and low runoff potential sites. The Wilcoxon signed-rank tests of the physical habitat variables indicated that instream cover, habitat volume, and geomophology variables differed between the open and wooded riparian cover sites. Primarily, the geomorphology variables differed between high and low runoff potential sites. No differences between the two classification factors could be determined for any substrate variable.

\section{Conclusion}

Fish community composition was significantly influenced by riparian cover and runoff potential as indicated by the analysis of IBI scores and species richness (fig. 3). Higher IBI scores were found at sites with wooded riparian cover and low runoff potential than at sites with open riparian cover and high runoff potential. Both factors explained significant percentages of variance in IBI scores and species richness. The riparian cover classification factor explained more of the variance in species richness than runoff potential. The riparian cover classification was the only factor that explained a significant percentage of variance in diversity. Thus, in the Minnesota River Basin, the local riparian cover appears to have more influence on fish community composition than the basin runoff potential.

Fish community composition seems to be more strongly influenced by the presence or absence of wooded riparian cover in basins with high runoff potential soils than in basins with low runoff potential soils. However, the amount of variance in IBI scores explained by the

Table 1.--Site characteristics by sample group. 


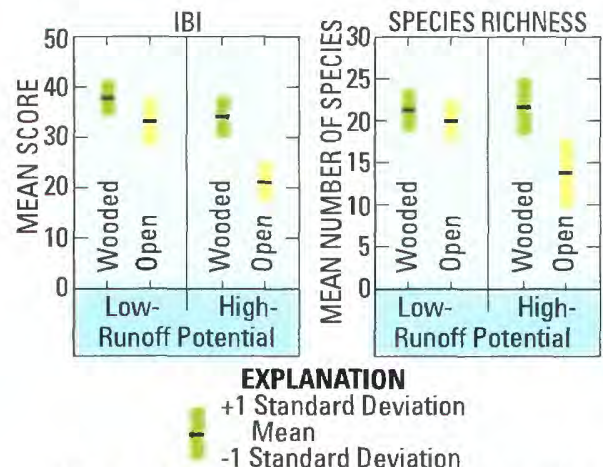

Fig. 3.--Mean Index of Biotic Integrity (IBI) scores and species richness of sample groups.

interaction was much lower than the factors separately.

Few physical habitat variables differed among classification factors. However, geomorphology, instream cover, and habitat volume were different between open and wooded riparian cover sites. This indicated that the fish communities were influenced by physical habitat conditions that were strongly related to wooded riparian cover.

This study suggests that wooded riparian cover could be effective in maintaining and improving fish community composition in streams in heavily agricultural basins. In agricultural basins with high runoff potential due to artificial drainage, wooded riparian cover could be important for protecting and maintaining healthy fish communities.

\section{References}

Allan, J.D., and Johnson, L.B., 1997 , Catchment-scale analysis of aquatic ecosystems: Freshwater Biology, no. 37, p. 107-111.

Bailey, P.A., Enblom, J.W., Hanson, S.R., Renard, P.A., and Schmidt, K., 1993, A fish community analysis of the Minnesota River Basin in Minnesota River Assessment Project Report, v. 3: Minnesota Pollution Control Agency, St. Paul, Minn., p. 212

Gregory, S.V., Swanson, F.J., McKee, W.A., and Cummings, K.W., 1991, An ecosystem perspective of riparian zones-Focus on links between land and water: BioScience, no. 41, p. 540551

Hughes, R.M., Heiskary, S.A., Matthews, W.J., and Yoder, C.O. 1994. Use of ecoregions in biological monitoring in Biological monitoring of aquatic

For water information: Upper Mississippi River Basin - NAWQA Coordinator 2280 Woodale Drive, Mounds View, Minnesota 55112 (612) 7833100 http://wwwmn.cr.usgs.gov/umis systems. Ed. by S.L. Loeb and A. Spacie. Lewis Publishers, Boca Raton, FL. pp.125-151.

Johnson, L.B., Richards, C., Host, G.E., and Arthur, J.W. 1997. Landscape influences on water chemistry in Midwestern stream ecosystems: Freshwater Biology, v. 37, p. 193208.

Karr, J.R., 1981, Assessment of biotic integrity using fish communities: Fisheries, v. 6, no. 6, p. 21-27.

Karr, J. R. and Schlosser, I.J., 1978, Water resources and the land-water interface: Science, v. 201, p. 229 234.

Lenat, D.R., 1984, Agriculture and stream water quality - A biological evaluation of erosion control practices: Environmental Management, no. 8, p. 333-344.

Meador, M.R., Hupp, C.R., Cuffney, T.F., and Gurtz, M.E., 1993, Methods for characterizing stream habitat as part of the National Water-Quality

Assessment Program. U.S. Geological Survey Open-File Report $93-408$, p. 48.

Osborne, L.L., and Kovacic, D.A., 1993, Riparian vegetated buffer strips in water-quality restoration and stream management. Freshwater Biology, v. 29 , p. 243-258.

Pielou, E.C. 1975. Ecological diversity. Wiley, New York, NY, p. 165

Richards, C., Johnson, L.B., and Host, G.E., 1996, Landscape-scale influences on stream habitats and biota: Canadian Journal of Aquatic Sciences, v. 53, p. 295-310.

Sorenson, S.K., Porter, S.D., Akers, K.K.B., Harris, M.A., Kalkhoff, S.J., Lee, K.E., Roberts, L.R., and Terrio, P.J., 1999, Water quality and habitat conditions in Upper Midwest streams and rivers, U.S. Geological Survey Open-File Report 99-202, 53.p.

Southwood, T.R.E., 1977, Habitat, the template for ecological strategies: Journal of Animal Ecology, no. 46, p. 365-377.

Stauffer, J.C. 1998. Relation of wooded riparian zones and runoff potential to fish community composition in the agricultural Minnesota River Basin. M.S. thesis, University of Minnesota, St. Paul, MN.
Stauffer, J.C., Goldstien, R.M., and Newman, R.M., 2000, Relation of wooded riparian zones and runoff potential to fish community composition in the agricultural streams: Canadian Journal of Fisheries and Aquatic Sciences, v. 57, pp. $307-$ 316

U.S. Department of Agriculture, 1994, State soil geographic data base (STATSGO) data users guide: Soil Conservation Service Miscellaneous Publications Number 1492, Fort Worth, Texas, p. 88.

U.S. Geological Survey, 1980, National Aerial Photography Program (NAPP), electronic description: Sioux Falls, South Dakota, REOS Data Center.

U.S. Geological Survey, 1996, Standards for 1:24,000-Scale Digital Raster Graphics: National Mapping Program Technical Instructions, Rolla, Missouri.

Wolock, D.M., 1997, STATSGO soil characteristics for the conterminous United States: USGS Open-File Report 97-656, Lawerence, Kansas

\section{-Paul E. Hanson}

\section{National Water-Quality Assessment Program}

In 1991, the U.S. Geological Survey (USGS) began implementation of the National Water-Quality Assessment (NAWQA) Program. The goals of NAWQA are to describe the status and trends in the quality of the Nation's ground- and surface-water resources and to gain a better understanding of the natural and human factors that affect the quality of water resources. The 60 study units, which are distributed throughout the Nation, contribute to the overall goals of NAWQA by providing waterquality information that is relevant to the study unit and that can be used in combination with information from other study units to assess water quality at regional and National scales.
For more information contact any of the following: For more information on all USGS reports and products (including maps images, and computerized date), call 1-800-USA-MAPS
Additional earth science information can be found by accessing the USGS "Home Page" on the World Wide Web at "http://www.usgs.gov". 